\author{
Michat MichaŁKIEWICZ
}

Politechnika Poznańska

Instytut Inżynierii Środowiska

Berdychowo 4, 61-138 Poznań

E-mail: Michal.Michalkiewicz@put.poznan.pl

\title{
METODY BADAŃ MIKROBIOLOGICZNEGO ZANIECZYSZCZENIA POWIETRZA NA TERENACH OCZYSZCZALNI ŚCIEKÓW - PRZEGLĄD LITERATUROWY
}

\section{WSTEP}

Bioaerozole obecne w atmosferze występują w postaci wirusów, bakterii, zarodników grzybów, pyłków, metabolitów, toksyn, alergenów i fragmentów roślin i zwierzat. Wielkość cząstek bioaerozoli waha się od 0,005 do $100 \mu \mathrm{m}$. Ilość i jakość bioaerozoli zależy m.in. od źródła emisji, lokalizacji w terenie, warunków klimatycznych (temperatura, wilgotność, opady atmosferyczne, wiatr), promieniowania słonecznego i pory roku. Ze względu na dość zróżnicowany skład bioerozolu występującego w otaczajacym nas środowisku oraz jego negatywne oddziaływanie na człowieka, zaleca się prowadzenie badań zarówno powietrza zewnętrznego, zwłaszcza w sassiedztwie potencjalnych emitorów zanieczyszczeń, jak i wewnętrznego. Zagrożenie dla zdrowia ludzi wynika $z$ obecności czynników chorobotwórczych, które przenoszone sa droga powietrzna do naszych dróg oddechowych i na powłoki ciała, powodując infekcje, podrażnienia, reakcje alergiczne i toksyczne (BRANDI i współaut. 2000, FRACCHIA i współaut. 2006, CYPROWsKI i współaut. 2008, KoRZENIEWSKA 2011, GUO i współaut. 2014, ADAMUS-BIAŁEK i współaut. 2015, TOMASI i LUPI 2017).

Znanych jest kilka metod pobierania i badania próbek powietrza atmosferycznego pod katem obecnych w nim zanieczyszczeń mikrobiologicznych. Niestety, do tej pory nie doczekaliśmy się ani jednej referencyjnej, światowej, zalecanej i bardzo dokładnie opisanej metody takich badań. Ze względu na to, że każda ze stosowanych metod poboru próbek powietrza jest inna, niekiedy bardzo trudno jest porównać wyniki pomiarów prowadzonych przez różnych autorów. Oczyszczalnie ścieków sa jednym $z$ antropogennych źródeł emisji bioaerozoli, dlatego w tym artykule zostanie zwrócona uwaga na metody badań stosowane na terenie tych obiektów komunalnych. Należy jednocześnie mieć świadomość, że ze względu na lokalizację oczyszczalni ścieków w pobliżu skupisk ludzkich, obiekty te nie tylko moga stanowić potencjalne zagrożenie mikrobiologiczne dla mieszkajacych tam ludzi, ale powoduja również dyskomfort w odbiorze środowiska, m.in. ze względu na emisję odorów.

Oprócz problemów dotyczących poboru powietrza do badań pojawia się także druga trudność, zwiazana ze stosowaniem różnych pożywek (podłoży) do hodowli mikroorganizmów i warunków ich inkubacji. Zagadnienia te sa bardzo ważne, gdyż skład bioaerozolu emitowanego m.in. wokół oczyszczalni ścieków jest zróżnicowany i zależy zarówno od charakteru i rodzaju ścieków, jak i metod ich oczyszczania. Najczęściej w badaniach mikrobiologicznego zanieczyszczenia powietrza badane sa różne grupy bakterii, grzyby mikroskopowe oraz ich metabolity, a także prowadzona jest szczegółowa identyfikacja niektórych drobnoustrojów na pożywkach wybiórczych lub różnicujących. Aby ocenić stopień skażenia powietrza należy pobrać $z$ niego drobnoustroje i okraślić ich liczebność. Uzyskane wyniki przeliczane sa na wspólna jednostke $1 \mathrm{~m}^{3}$ powietrza. W Polsce od 1989 r. obowiazywały Polskie Normy dotyczace metod poboru i badań mikrobiologicznego zanieczyszczenia powietrza 
(PN-89/Z-04111/01, PN-89/Z-04111/02, PN-89/Z-04111/03, PN-89/Z-04008/08), w których podawano graniczne wartości trzech stopni zanieczyszczenia powietrza wybranymi bakteriami i grzybami mikroskopowymi. W innych państwach najczęśsiej nie było takich przepisów, lub były całkowicie odmienne.

W celu stwierdzenia koncentracji oraz składu bakterii i grzybów mikroskopowych występujacych w powietrzu, stosuje się najczęściej trzy podstawowe grupy metod badawczych: mikroskopowe, hodowlane i metaboliczne (KRZYSZTOFIK 1992, BARTLETT i współaut. 2002, DUTKIEWICZ i GÓRNY 2002, KROGULSKI 2006, PN-89/Z-04111/01, PN $-89 / Z-04111 / 02$, PN-89/Z-04111/03, PN$-89 / Z-04008 / 08)$.

\section{METODY BADAŃ BIOAEROZOLU}

\section{METODA MIKROSKOPOWA}

Badania prowadzone ta metoda polegaja na poborze próbki powietrza atmosferycznego na filtr membranowy, a następnie policzeniu pod mikroskopem liczby komórek drobnoustrojów (bakterii i grzybów) i przeliczeniu uzyskanych wyników na $1 \mathrm{~m}^{3}$ powietrza atmosferycznego. W metodzie tej można również stosować szkiełka, na których znajduje się lepka substancja (np. żelatyna z gliceryna), do której przyklejaja się opadajace drobnoustroje (AIzENBERG i współaut. 2000, MARTINEz i współaut. 2004, PATENTALAKIS i współaut. 2008).

\section{METODY HODOWLANE}

Metody te polegaja na poborze próbki powietrza atmosferycznego na przygotowane podłoża stałe (agarowe) lub płynne o odpowiednim składzie ( $\mathrm{w}$ zależności od badanych mikroorganizmów), a następnie po okresie hodowli (inkubacji w optymalnych warunkach dla danej grupy mikroorganizmów) obliczeniu liczby zdolnych do rozwoju drobnoustrojów w określonej objętości powietrza. Wynik ostateczny podawany jest jako jtk/1 $\mathrm{m}^{3}$ lub $\mathrm{CFU} / 1 \mathrm{~m}^{3}$ (jednostki tworzace kolonie; ang. colony forming units). Sa to najczęściej stosowane metody badawcze, gdyż $\mathrm{z}$ uzyskanych $\mathrm{w}$ hodowli mikroorganizmów można przeprowadzić dalsza ich identyfikację (np. do rodzaju lub gatunku). Znanych jest kilka sposobów poboru próbek powietrza, które wykorzystane sa w metodach hodowlanych.

\section{METODY MOLEKULARNE I METABOLICZNE}

Metody te najczęściej stosowane sa do oznaczenia DNA lub produktów metabolizmu drobnoustrojów, np. metody łańcuchowej re- akcji polimerazy (ang. polymerase chain reaction, PCR), a także stosuje się różne testy diagnostyczne, np. bioluminescencji ATP, test LAL (do oznaczania endotoksyny) lub testy biochemiczne API do dokładnego oznaczenia wybranych gatunków mikroorganizmów. Używajac różnych testów API można zidentyfikować m.in. Gram-ujemne pałeczki $z$ rodziny Enterobacteriaceae (API 20E, Rapid 20E), Gram-ujemne bakterie niefermentujace glukozy (API 20NE), gronkowce i inne bakterie $z$ rodziny Micrococcaceae (API Staph), paciorkowce (API STREP), beztlenowce (API 20A), drożdżaki (API Candida, API 20C AUX), Lactobacillus (API 50CHL), czy Bacillus (API 50CHB). Metody te stosowane były m.in. w licznych badaniach powietrza na terenach oczyszczalni ścieków (KARL 1980; ALVAREZ i współaut. 1995; MACNEIL i współaut. 1995; MROWIEC i SUSCHKA 1995; STEWART i współaut. 1997; RANALLI i współaut. 2000; WILLIAMS i współaut. 2001; ORSINI i współaut. 2002; THORN i współaut. 2002; SCHAFER i współaut. 2003; ZENG i współaut. 2004; CYPROWSKI i wspólaut. 2006, 2018; MICHAEKIEWICZ 2006; FILIPKOWSKA i współaut. 2008; KORZENIEWSKA i współaut. 2008; GotKOWSKA-PŁACHTA i współaut. 2008; KIM i współaut. 2011, VANTARAKIS i współaut. 2016; KOWALSKI i współaut. 2017).

\section{METODY POBIERANIA POWIETRZA DO BADAN BIOAEROZOLI}

Badania bioaerozoli oparte sa na pobraniu (zbadaniu) określonej objętości powietrza i wykryciu w nim obecnych mikroorganizmów. Objętość pobieranego powietrza uzależniona jest od stopnia jego zanieczyszczenia, a także prawdopodobnej liczebności analizowanych drobnoustrojów. W wielu przypadkach dla wyhodowania i określenia ogólnej liczebności bakterii i grzybów mikroskopowych pobiera się mniejsza objętość powietrza, natomiast dla wykrycia np. wybranych drobnoustrojów wskaźnikowych, których liczebność w atmosferze może być mniejsza, pobieramy do badań wiẹksza objętość powietrza. Podczas badań należy kierować sie zasada, że w efekcie końcowym musimy określić liczbe wszystkich mikroorganizmów, dlatego objętość badanego powietrza powinna być taka, aby nie popełnić błędów podczas liczenia wyrosłych kolonii. Zalecane jest pobieranie kilku próbek o różnej objętości powietrza.

\section{METODA SEDYMENTACYJNA KOCHA}

Jest to jedna $z$ najstarszych $i$ najprostszych metod mikrobiologicznego badania powietrza. Polega na swobodnym opadaniu (sedymentacji) czasstek wraz $z$ drobnoustroja- 
mi na zestaloną pożywkę na płytce Petriego. Chcąc określić liczebność różnych drobnoustrojów należy przygotować płytki Petriego z odpowiednimi pożywkami. Czas ekspozycji płytek może być zróżnicowany, w zależności od spodziewanego stopnia zanieczyszczenia powietrza i wynosi zwykle od 10 do 30 minut. W metodzie tej nie zawsze wszystkie drobnoustroje zostaja wychwycone, gdyż bardzo drobne składniki bioaerozolu maja długi czas sedymentacji i nie opadna na eksponowane płytki Petriego. Badania powietrza ta metoda prowadziło wielu badaczy (FILIPKOWSKA i współaut. 2000, 2008; KRUCZALAK i OlAŃCZUK-NEYMAN 2004; KROGULSKI 2006; KORZENIEWSKA i współaut. 2007, 2008; GOTKOWSKA-PŁACHTA i współaut. 2008, 2013; GRISOLI i współaut. 2009; MICHAŁKIEWICZ i współaut. 2011; KoŁWZAN i współaut. 2012a, b; Seetha i współaut. 2013; AdAmus-BiateK i współaut. 2015).

\section{METODY OBJETOŚCIOWE (WOLUMETRYCZNE)}

Oparte sa one na dokładnym poborze (badaniu) określonej objętości powietrza, przy użyciu specjalistycznych przyrząóow (urzadzenia wolumetryczne: aspiratory, impaktory, aeroskopy). Urządzenia te różnia się konstrukcja, wielkościa, sposobem poboru i przepływu powietrza, liczba i wielkościa dysz, ale ze względu na łatwość obsługi i stosunkowo dostępne ceny sa one najczęściej wykorzystywane w monitoringu powietrza.

\section{METODA ZDERZENIOWA}

W metodzie tej strumień powietrza uderza o lepkie podłoże (najczęściej pożywkę agarowa) powodując, że cząstki w nim zawieszone przylepiaja się do pożywki. W ten sposób drobnoustroje zostaja wychwycone $z$ badanej objętości powietrza. Metoda ta nazywana jest również impakcyjna, a urządzenia, którymi pobiera się odmierzony strumień powietrza - impaktorami. Znanych jest wiele urządzeń działających na zasadzie metody zderzeniowej m.in.:

- Kaskadowy impaktor Andersena (ACI) firmy Tisch Environmental, Inc., USA

Dostępne sa sześcio- lub ośmiostopniowe urządzenia, w których każdy stopień ma 400 otworów o malejącej średnicy. Na każdym poziomie można zainstalować płytkę Petriego $z$ pożywka agarową. ACI pracuja przy natężeniu przepływu powietrza 28,3, 60 lub $90 \mathrm{dm}^{3} / \mathrm{min}$. Podczas badań istnieje możliwość analizowania cząstek pod względem wielkości. Końcowa liczebność wyhodowanych mikroorganizmów poprawiana jest przez współczynnik korekcyjny załączony do instrukcji urzadzenia. Impaktor ten stosowany był w licznych badaniach mikrobiolo- gicznego zanieczyszczenia obiektów komunalnych (ANDERSEN 1958, GOFF i współaut. 1973, FANNIN i współaut. 1985, THORNE i współaut. 1992, SAWYER i współaut. 1993, MARCHAND i współaut. 1995, BRANDI i współaut. 2000, BELLIN i SCHILlinger 2001, WLAZŁO i współaut. 2002, HEINONEN-TANSKI i współaut. 2009, HUNG i współaut. 2010, BRĄGOSZEWSKA i współaut. 2013, Li i współaut. 2013, MALAKOOTIAN i współaut. 2013, PASTUSZKA i współaut. 2013, GUO i współaut. 2014, DING i współaut. 2015, SHRAVANTHI i współaut. 2016, FATHI i współaut. 2017, KOWALSKI i współaut. 2017, UHRBRAND i współaut. 2017, CYPROWSKI i współaut. 2018, WANG i współaut. 2018).

- Próbniki serii MAS-100 firmy MERCK, Niemcy

MAS-100 Eco ${ }^{\circledR}$ przystosowany jest do pracy ze standardowymi płytkami Petriego o średnicy $90 \mathrm{~mm}$ i idealnie nadaje się do monitoringu powietrza w przemyśle spożywczym oraz powietrza zewnętrznego. Natężenie przepływu powietrza wynosi $100 \mathrm{dm}^{3} / \mathrm{min}$. W głowicy próbnika znajduje się 400 otworów. Automatyzacja urządzenia daje możliwość poboru próbki powietrza w zakresie od 1 do $1000 \mathrm{dm}^{3}$. Używanie próbnika zatwierdzone jest przez liczne normy (np. EN 50082-1,1997, ISO 14698-1/2, 2003).

Liczebność wyrosłych kolonii jest korygowana przy użyciu tablicy poprawek statystycznych według Fellera. $Z$ tablicy tej dla każdego zliczenia kolonii (r), można odczytać jego poprawiona prawdopodobna wartość (Pr). Próbniki MAS-100 NT® i MAS-100 NT® Ex - zalecane sa do mikrobiologicznego monitoringu powietrza. Posiadaja automatyczna kalibrację i przystosowane sa do pracy $z$ płytkami Petriego o średnicy $90 \mathrm{~mm}$ lub kompaktowymi o średnicy $60 \mathrm{~mm}$. Zasada działania urządzeń wzorowana jest na próbniku Andersena. Głowica posiada 300 otworów o średnicy 0,6 $\mathrm{mm}$, co zwiększa skuteczność poboru mikroorganizmów z powietrza, przy natężeniu przepływu powietrza $100 \mathrm{dm}^{3} / \mathrm{min}$. Próbniki przeznaczone sa głównie dla przemysłu spożywczego i ochrony środowiska.

Próbniki serii MAS-100 używane były w licznych badaniach powietrza na terenach oczyszczalni ścieków (PASCUAL i współaut. 2003; KRUCZALAK i OLAŃCZUK-NEYMAN 2004; BRANDL i współaut. 2005; BREZA-BORUTA i PALUSZAK 2007a, b; KARRA i KATSIVELA 2007; KORZENIEWSKA i współaut. 2007; FILIPKOWSKA i współaut. 2008; GREGOVÁ i współaut. 2008; PATENTALAKIS i współaut. 2008; HAAS i współaut. 2010; MAEECKA-ADAMOWICZ i współaut. 2011, 2016; MICHAŁKIEWICZ i współaut. 2011, 2018; VÍTĚZOVÁ i współaut. 2012; TEIXEIRA i współaut. 2013; AZEVE- 
DO i współaut. 2014; PAŚMIONKA i współaut. 2015; BREZA-BORUTA 2016; SZYŁAK-SZYDŁOWSKI i współaut. 2016).

- Air IDEAL ${ }^{\mathrm{P}}$ 3P ${ }^{\mathrm{TM}}$ firmy bioMèrieux, Marcy l'Etoile, Francja

Jest to urządzenie przeznaczone głównie do mikrobiologicznego monitorowania zanieczyszczenia powietrza w pomieszczeniach placówek szpitalnych, farmaceutycznych i przemysłowych. Aparat przystosowano do płytek Petriego o średnicy 90 i $65 \mathrm{~mm}$. Natężenie przepływu powietrza wynosi 100 $\mathrm{dm}^{3} / \mathrm{min}$. Praca urzadzenia jest zgodna $z$ obowiąujacymi normami. Próbnik ten używany był m.in. w badaniach powietrza na terenach oczyszczalni (ÖZDEMIR i współaut. 2010, M`EHEUST i współaut. 2013, PASTUSZKA i współaut. 2013).

- Próbniki serii SAS firmy PBI International, Włochy

DUO SAS Super 360 ma pojedynczy korpus $z$ dwiema głowicami zasysajacymi (487 otworów) i pracuje przy natężeniu przepływu powietrza 180 lub $360 \mathrm{dm}^{3} / \mathrm{min}$. Można w nim stosować płytki Rodac $55 \mathrm{~mm}$ lub Petriego o średnicy $90 \mathrm{~mm}$.

SAS Super ISO 100/180 ma pojedynczy korpus $z$ jedna głowica zasysajaca, jest w nim możliwość stosowania płytek Rodac 55 $\mathrm{mm}$ lub Petriego o średnicy $90 \mathrm{~mm}$ i pracuje przy natężeniu przepływu powietrza 100 lub $180 \mathrm{dm}^{3} / \mathrm{min}$.

SAS Super IAQ ma dajaca się programować objętość zasysanego powietrza od 1 do $1999 \mathrm{dm}^{3}$ przy natężeniu przepływu powietrza $100 \mathrm{dm}^{3} / \mathrm{min}$. Przygotowany jest do pracy ze standardowymi płytkami kontaktowymi Rodac $55 \mathrm{~mm}$ i płytkami Petriego o średnicy $90 \mathrm{~mm}$. Próbniki serii SAS stosowane były podczas badań powietrza na terenach obiektów komunalnych (MROWIEC i SUSCHKA 1995, BRANDI i współaut. 2000, RANALLI i współaut. 2000, BELLIN i SCHILLINGER 2001, ORSINI i współaut. 2002, FRACCHIA i współaut. 2006, BUDZIŃSKA i współaut. 2011, VANTARAKIS i współaut. 2016).

- Selektywny aerobioskop

Próbnik ten został skonstruowany i opatentowany w Polsce przez Instytut Medycyny Wsi w Lublinie i powinien trafić do seryjnej produkcji. Umożliwia pobór bioaerozolu w celu określenia ogólnej liczby mikroorganizmów oraz najdrobniejszej frakcji wnikajacej do dróg oddechowych. Powietrze uderza przez dysze na dwie obracajace się płytki Petriego $z$ pożywka (DUTKIEWICZ i GÓRNY 2002).

\section{- Inne próbniki}

Próbnik do pobierania stałych czassteczek zawieszonych TH-150C zostal wykorzystany w badaniach HAN i współaut. (2018), polegajacych na filtracji powietrza przez jałowy filtr kwarcowy Whatman QM-A, który po homogenizacji w jałowej wodzie był podstawa do posiewów na płytki z pożywka agarowa.

Próbnik Burkard Aerosol Sampler, opisany w pracy CYPROWSKI i współaut. (2008), działa na zasadzie metody zderzeniowej $z$ wykorzystaniem płytek Petriego o średnicy $90 \mathrm{~mm}$

\section{METODA FILTRACYJNA}

Sposób pobierania powietrza w tej metodzie polega na absorpcji bioaerozolu w płynie absorpcyjnym, który znajduje się w płuczce, lub na specjalny filtr membranowy. Drobnoustroje zawarte w płynie lub wypłukane $z$ filtra posiewa się na odpowiednie pożywki. Na tej metodzie oparte sa m.in. następujace urządzenia:

- Impinger AGI 30 firmy Ace Glass Incorporated, USA

Uważany jest za jedno $z$ najbardziej skutecznych urządzeń do przechwytywania cząstek bioaerozolu o wielkości od $0,8 \mu \mathrm{m}$ do 15,0 $\mu \mathrm{m}$, przy natężeniu przepływu powietrza $12,5 \mathrm{dm}^{3} / \mathrm{min}$. Strumień powietrza za pomoca kapilarnej rurki kierowany jest w pobliże dna szklanego naczynia wypełnionego od 2 do $20 \mathrm{ml}$ płynu absorpcyjnego. AGI 30 używano m.in. do badania powietrza na terenie obiektów komunalnych (MAY i HARPER 1957, THORNE i współaut. 1992, LIN i LI 1999, BRANDI i współaut. 2000, DING i WANG 2001).

- SKC BioSampler firmy SKC Ltd., Wielka Brytania

Urządzenie to wzorowane jest na impingerze AGI. Przepływ powietrza odbywa się przez trzy dysze, w każdej 4,2 $\mathrm{dm}^{3} / \mathrm{min}$ (łaczny przepływ ok. 12,5 $\mathrm{dm}^{3} / \mathrm{min}$ ). Układ dysz powoduje jednocześnie wprowadzenie cieczy absorpcyjnej w ruch wirowy, co zwiększa skuteczność pochłaniania mikroorganizmów. Próbnik ten stosowany jest przez badaczy powietrza (PATENTALAKIS i współaut. 2008, HAAS i współaut. 2010, GANGAMMA i współaut. 2011, AHMED i współaut. 2013, LI i współaut. 2016).

- Płuczka Zajcewa

Jest zalecana przez Polskie Normy PN$-89 / Z-04111 / 02$ i PN-89/Z-04111/03 do mikrobiologicznego badania powietrza. Zasada działania polega na zasysaniu powietrza przez szklana rurke, która zanurzona jest w płynie absorpcyjnym.

\section{METODA ELEKTROPRECYPITACJI}

Metoda wykorzystuje zjawisko posiadania ładunku elektrycznego przez drobnoustroje, które zostaja przyciagnięte do podłaczonych do prąu płytek Petriego, pełniacych rolę elektrod. Odbywa się to w urządzeniach zwanych precypitatorami. 
W samplerach pobierane próbki powietrza zawierajace cząstki aerozoli o różnej wielkości uderzają w lepkie podłoże (pożywki stałe lub płynne) powodując, że część frakcji zostaje zatrzymana na podłożu, a część ulega odbiciu lub przelatuje wraz ze strumieniem powietrza. Prędkość przepływu powietrza i zdolność osadzania czastek zależą od kształtu, wielkości, ilości dysz i odległości uderzenia powietrza o lepkie podłoże, a także średnicy cząstek, ich gęstości i lepkości podłoża. Na podstawie tych danych można określić tzw. wydajność impaktora i wielkość odcięcia $\left(\mathrm{d}_{50}\right)$, czyli wartość wskazującą, że 50\% cząstek o różnej średnicy zostaje zatrzymanych na pożywce, a 50\% przechodzi przez impaktor. Zwykle przyjmuje się, że $\mathrm{d}_{50}$ jest to średnica czastki, powyżej której wszystkie większe cząstki zostaja w całości zebrane. Wartość średnicy odcięcia jest ważna cecha każdego impaktora, jednak znana jest ona tylko dla kilku samplerów. W różnych samplerach natężenie przepływu powietrza jest zróżnicowane i waha się od 10 do $180 \mathrm{dm}^{3} / \mathrm{min}$. Moga one posiadać jedna lub kilka dysz. Graniczne wartości $\mathrm{d}_{50}$ moga być zróżnicowane i wahają się od mniej niż 0,4 $\mu \mathrm{m}$ (AGI-30) do ponad $6 \mu \mathrm{m}$ (ACI-I). Dlatego przy porównywaniu wyników badań powinno się wykorzystywać urządzenia o podobnej średnicy odcięcia. Na wartość końcowa obliczeń (jtk $/ \mathrm{m}^{3}$ ) ma także wpływ czas poboru próbki oraz powierzchnia zasysania powietrza, liczba i wielkość otworów w głowicy, a także przeżywalność i żywotność pobranych mikroorganizmów. Ponieważ można przyjąć, że np. w jeden otwór głowicy (w przypadku próbnika Andersena, MAS-100 Eco jest 400 otworów) wpadaja dwa drobnoustroje, które tworza po okresie hodowli jedna widoczna kolonię, a w inny otwór nie wpadnie żaden mikroorganizm, dlatego do obliczeń końcowych przyjmuje się korektę wyników według tabeli statystycznych obliczeń Fellera wyrażonych wzorem:

$$
\mathrm{P}_{\mathrm{r}}=\mathrm{N}[1 / \mathrm{N}+\underset{(\mathrm{N}-\mathrm{r}+1)]}{1 /(\mathrm{N}-1)+1 /(\mathrm{N}-2)+\ldots+1 /}
$$

w którym:

$\mathrm{P}_{\mathrm{r}}$ - wynik końcowy po korekcji (jtk $/ \mathrm{m}^{3}$ )

$\mathrm{N}^{\mathrm{r}}$ - liczba otworów w głowicy impaktora $\mathrm{r}$ - liczba kolonii na płytce $\left(\mathrm{jtk} / \mathrm{m}^{3}\right)$

Aby mieć pewność, że badania wykonywane sa zgodnie $z$ założeniami producenta samplera, należy również przeprowadzać (samodzielnie lub w serwisie) okresowa kalibracje przyrzacdu przy zastosowaniu danej prędkości przepływu powietrza (NEVALAINEN i współaut. 1992, YAO i MAINELIS 2006, PASTUSZKA i współaut. 2013).

Ryc. 1-7 przedstawiaja przykładowe samplery wykorzystywane $\mathrm{w}$ badaniach mikrobiologicznych powietrza.

Obecnie do badań mikrobiologicznych na terenach oczyszczalni ścieków najczęściej wykorzystuje się metody wolumetryczne, a wśród urządzeń dominują próbniki serii
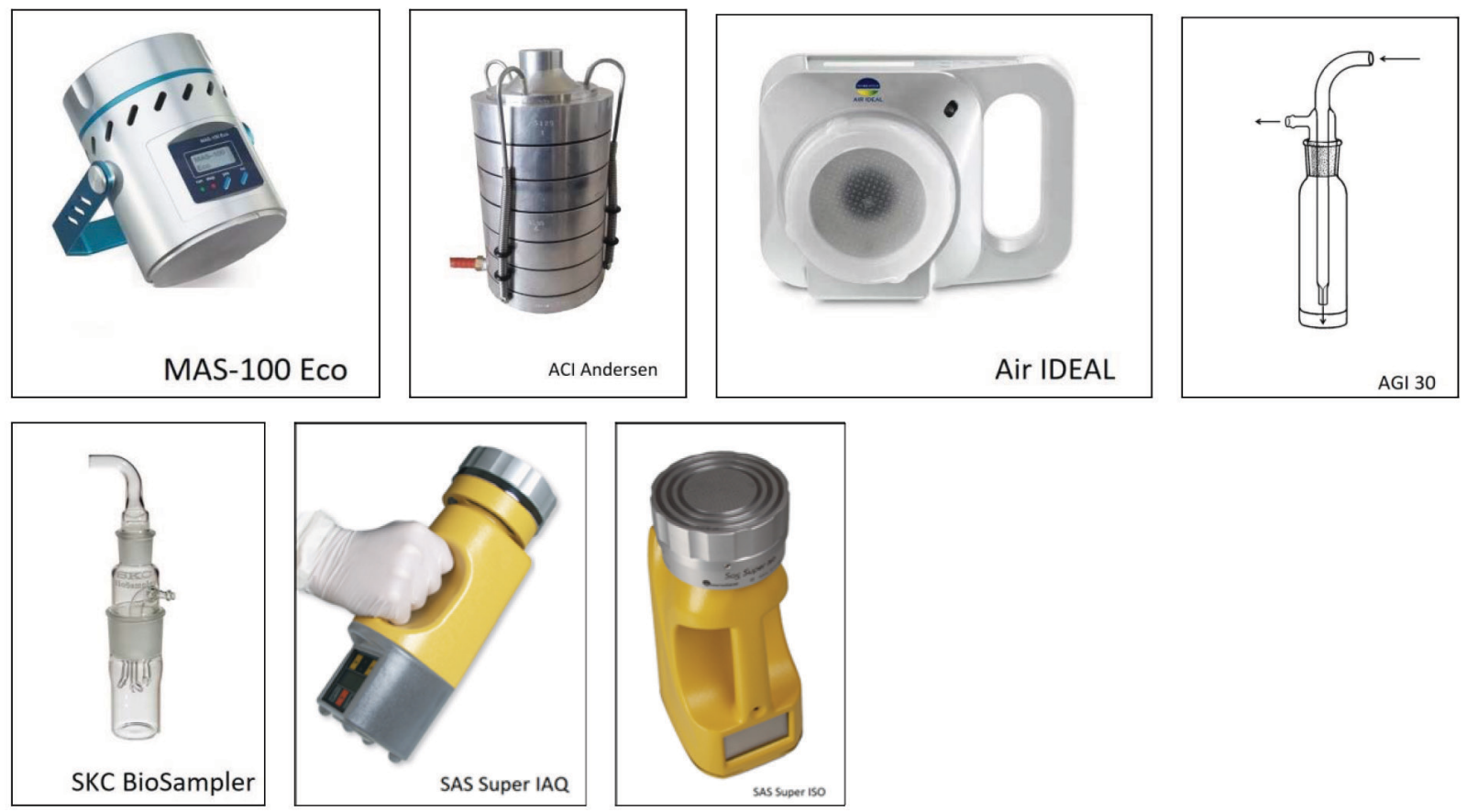

Ryc. 1-7. Samplery do mikrobiologicznych badań powietrza (1 - MAS-100 Eco; 2 - ACI Andersen; 3 Air IDEAL; 4 - AGI 30; 5 - SKC BioSampler; 6 - SAS Super IAQ; 7 - SAS Super ISO). 
Tabela 1. Podłoża i warunki hodowli bakterii stosowane w badaniach mikrobiologicznego zanieczyszczenia powietrza.

\begin{tabular}{|c|c|c|c|}
\hline Grupa bakterii & Podłoże & $\begin{array}{l}\text { Warunki } \\
\text { hodowli }\end{array}$ & Autor \\
\hline $\begin{array}{l}\text { Całkowita liczba } \\
\text { bakterii }\end{array}$ & Agar odżywczy & $30^{\circ} \mathrm{C}, 48 \mathrm{~h}$ & GUO i współaut. 2014; HAN i współaut. 2018 \\
\hline $\begin{array}{l}\text { Całkowita liczba } \\
\text { bakterii }\end{array}$ & $\begin{array}{l}\text { Agar drożdżowy } \\
\text { z tryptonem i } \\
\text { glukoza }\end{array}$ & $37^{\circ} \mathrm{C}$ & BRANDI i współaut. 2000 \\
\hline $\begin{array}{l}\text { Bakterie hetero- } \\
\text { troficzne }\end{array}$ & Agar bulionowy & $26^{\circ} \mathrm{C}, 72 \mathrm{~h}$ & $\begin{array}{l}\text { FILIPKOWSKA i współaut. 2000; KORZENIEWSKA i współaut. } \\
2009\end{array}$ \\
\hline $\begin{array}{l}\text { Bakterie mezo- } \\
\text { filne }\end{array}$ & Agar wzbogacony & $37^{\circ} \mathrm{C}, 24-48 \mathrm{~h}$ & $\begin{array}{l}\text { HAAS i współaut. 2010; GOTKOWSKA-PŁACHTA i współaut. } \\
\text { 2013; LI i współaut. 2013; ADAMUS-BIAŁEK i współaut. } \\
\text { 2015; PAŚMIONKA i współaut. } 2015\end{array}$ \\
\hline $\begin{array}{l}\text { Bakterie mezo- } \\
\text { filne }\end{array}$ & Agar odżywczy & $37^{\circ} \mathrm{C}, 24-72 \mathrm{~h}$ & $\begin{array}{l}\text { BREZA-BORUTA i PALUSZAK 2007b; BREZA-BORUTA 2016; } \\
\text { KRUCZALAK i OlAŃCZUK-NEYMAN 2004; KARRA i KATSIVELA } \\
\text { 2007; GOTKOWSKA-PEACHTA i współaut. 2008; BUDZIŃSKA i } \\
\text { współaut. 2011; MiCHAŁKIEWICZ i współaut. 2011; KOEW- } \\
\text { ZAN 2012b; VÍTĚZOVÁ i współaut. 2012; SZYŁAK-SZYDŁOWSKI } \\
\text { i współaut. } 2016\end{array}$ \\
\hline $\begin{array}{l}\text { Bakterie mezo- } \\
\text { filne }\end{array}$ & Agar TSA & $\begin{array}{l}30-37^{\circ} \mathrm{C}, 1-7 \\
\text { dni }\end{array}$ & $\begin{array}{l}\text { BAUER i współaut. 2002; GRISOLI i współaut. 2009; BAUER } \\
\text { i współaut. 2002; GANGAMMA i współaut. 2011; TEIXEIRA } \\
\text { i współaut. 2013; NIAZI i współaut. 2015; LI i współaut. } \\
\text { 2016; MAEECKA-ADAMOWICZ i współaut. 2016; KRISTANTO i } \\
\text { ROSANA } 2017\end{array}$ \\
\hline $\begin{array}{l}\text { Bakterie mezo- } \\
\text { filne }\end{array}$ & Agar bulionowy & $37^{\circ} \mathrm{C}, 24 \mathrm{~h}$ & $\begin{array}{l}\text { FILIPKOWSKA i współaut. 2000; KORZENIEWSKA i współaut. } \\
2009\end{array}$ \\
\hline $\begin{array}{l}\text { Bakterie mezo- } \\
\text { filne }\end{array}$ & R2A Agar & $37^{\circ} \mathrm{C}, 48-120 \mathrm{~h}$ & MICHAEKIEWICZ i współaut. 2018 \\
\hline $\begin{array}{l}\text { Bakterie mezo- } \\
\text { filne Gram-do- } \\
\text { datnie }\end{array}$ & Agar $\mathrm{z}$ krwia & $\begin{array}{l}37^{\circ} \mathrm{C}, 24 \mathrm{~h} ; \\
22^{\circ} \mathrm{C}, 48 \mathrm{~h} ; 4^{\circ} \mathrm{C} \\
72 \mathrm{~h}\end{array}$ & WLAZŁO i współaut. 2002 \\
\hline $\begin{array}{l}\text { Bakterie Gram- } \\
\text {-dodatnie }\end{array}$ & $\begin{array}{l}\text { Agar } z \text { manni- } \\
\text { tolem }\end{array}$ & $37^{\circ} \mathrm{C}, 48 \mathrm{~h}$ & TEIXEIRA i współaut. 2013 \\
\hline $\begin{array}{l}\text { Bakterie mezofil- } \\
\text { ne Gram-ujemne }\end{array}$ & $\begin{array}{l}\text { Agar EMB }(z \\
\text { eozyna i błękitem } \\
\text { metylenowym) }\end{array}$ & $\begin{array}{l}37^{\circ} \mathrm{C}, 24 \mathrm{~h} ; \\
22^{\circ} \mathrm{C}, 48 \mathrm{~h} ; 4^{\circ} \mathrm{C}, \\
72 \mathrm{~h}\end{array}$ & WLAZŁO i współaut. 2002 \\
\hline $\begin{array}{l}\text { Bakterie Gram- } \\
\text {-ujemne }\end{array}$ & $\begin{array}{l}\text { Agar Mac Con- } \\
\text { key }\end{array}$ & $37^{\circ} \mathrm{C}, 24-48 \mathrm{~h}$ & $\begin{array}{l}\text { FRACCHIA i współaut. 2006; NOWOJEWSKI i MNISZEK 2006; } \\
\text { TEIXEIRA i współaut. } 2013\end{array}$ \\
\hline $\begin{array}{l}\text { Bakterie psy- } \\
\text { chrofilne }\end{array}$ & Agar odżywczy & $20-22^{\circ} \mathrm{C}, 72 \mathrm{~h}$ & $\begin{array}{l}\text { KRUCZALAK i OLAŃCZUK-NEYMAN 2004; GOTKOWSKA-PŁACH- } \\
\text { TA i współaut. 2008; MICHAEKIEWICZ i współaut. 2011; } \\
\text { VÍTÉZOVÁ i współaut. } 2012\end{array}$ \\
\hline $\begin{array}{l}\text { Bakterie psy- } \\
\text { chrofilne }\end{array}$ & R2A Agar & $\begin{array}{l}20-22^{\circ} \mathrm{C}, 72- \\
120 \mathrm{~h}\end{array}$ & $\begin{array}{l}\text { HEINONEN-TANSKI i współaut. 2009; MICHAEKIEWICZ i wspó1- } \\
\text { aut. } 2018\end{array}$ \\
\hline $\begin{array}{l}\text { Bakterie psy- } \\
\text { chrofilne }\end{array}$ & $\begin{array}{l}\text { Agar PCA } \mathrm{z} \text { cy- } \\
\text { kloheksamidem }\end{array}$ & $22^{\circ} \mathrm{C}, 72 \mathrm{~h}$ & KOŁWZAN i współaut. 2012a \\
\hline $\begin{array}{l}\text { Bakterie psy- } \\
\text { chrofilne }\end{array}$ & Agar TSA & $\begin{array}{l}20-22^{\circ} \mathrm{C}, 3-7 \\
\mathrm{dni}\end{array}$ & KOWALSKI i współaut. 2017; WLAZŁO i współaut. 2002 \\
\hline $\begin{array}{l}\text { Bakterie psy- } \\
\text { chrofilne }\end{array}$ & $\begin{array}{l}\text { Agar } z \text { ekstrak- } \\
\text { tem drożdżowym }\end{array}$ & $22^{\circ} \mathrm{C}, 72 \mathrm{~h}$ & NOWOJEWSKI i MNISZEK 2006 \\
\hline $\begin{array}{l}\text { Pseudomonas } \\
\text { fluorescens i } \\
\text { Pseudomonas } \\
\text { sp. }\end{array}$ & King B & $\begin{array}{l}26-30^{\circ} \mathrm{C}, 2-7 \\
\text { dni }\end{array}$ & $\begin{array}{l}\text { BREZA-BORUTA 2016; BREZA-BORUTA i PALUSZAK 2007b; BU- } \\
\text { DZIŃSKA i współaut. 2011; FILIPKOWSKA i współaut. 2000; } \\
\text { GOTKOWSKA-PŁACHTA i współaut. 2008; GOTKOwSKA-PŁACH- } \\
\text { TA i współaut. 2013; KOŁWZAN i współaut. 2012b; KORZE- } \\
\text { NIEWSKA i współaut. 2009; KRUCZALAK i OLAŃCZUK-NEYMAN } \\
\text { 2004; MICHAEKIEWICZ i współaut. } 2011\end{array}$ \\
\hline $\begin{array}{l}\text { Pseudomonas } \\
\text { fluorescens }\end{array}$ & $\begin{array}{l}\text { King B z cyklo- } \\
\text { heksamidem }\end{array}$ & $\begin{array}{l}4 \text { i } 26^{\circ} \mathrm{C}, 3-7 \\
\text { dni }\end{array}$ & KOŁWZAN i współaut. 2012a \\
\hline Pseudomonas sp. & King A & $37^{\circ} \mathrm{C}, 48 \mathrm{~h}$ & FILIPKOWSKA i współaut. 2000 \\
\hline
\end{tabular}




\begin{tabular}{|c|c|c|c|}
\hline $\begin{array}{l}\text { Pseudomonas } \\
\text { sp. }\end{array}$ & $\begin{array}{l}\text { Agar } z \text { cetrymi- } \\
\text { dem }\end{array}$ & $37^{\circ} \mathrm{C}, 24-48 \mathrm{~h}$ & AZEVEDO i współaut. 2014; NOWOJEWSKI i MNISZEK 2006 \\
\hline $\begin{array}{l}\text { Gronkowce } \\
\text { mannitolo-dodat- } \\
\text { nie i mannitolo- } \\
\text { ujemne }\end{array}$ & $\begin{array}{l}\text { Agar } z \text { mannito- } \\
\text { lem (Chapman) }\end{array}$ & $37^{\circ} \mathrm{C}, 24-48 \mathrm{~h}$ & $\begin{array}{l}\text { ADAMUS-BIAŁEK i współaut. 2015; BRANDI i współaut. } \\
\text { 2000; BREZA-BORUTA 2016; BUDZIŃSKA i współaut. } 2011 \text {; } \\
\text { FILIPKOWSKA i współaut. 2000; GOTKOwSKA-PŁACHTA i } \\
\text { współaut. 2013; GOTKOWSKA-PŁACHTA i współaut. 2008; } \\
\text { KOŁWZAN i współaut. 2012b; KORZENIEWSKA i współaut. } \\
\text { 2009; KRUCZALAK i OLAŃCZUK-NEYMAN 2004; MAŁECKA- } \\
\text {-ADAMOWICZ i współaut. 2016; MICHAŁKIEWICZ i współaut. } \\
\text { 2011; PAŚMIONKA i współaut. 2015; SZYŁAK-SZYDŁOWSKI i } \\
\text { współaut. } 2016\end{array}$ \\
\hline $\begin{array}{l}\text { Gronkowce he- } \\
\text { molizujace }\end{array}$ & $\begin{array}{l}\text { Agar wzbogacony } \\
\text { z krwia }\end{array}$ & $37^{\circ} \mathrm{C}, 48 \mathrm{~h}$ & $\begin{array}{l}\text { BUDZIŃSKA i współaut. 2011; GOTKOWSKA-PŁACHTA i współ- } \\
\text { aut. } 2008\end{array}$ \\
\hline $\begin{array}{l}\text { Gronkowce he- } \\
\text { molizujące }\end{array}$ & Agar $z$ krwia & $22^{\circ} \mathrm{C}, 72 \mathrm{~h}$ & KRUCZALAK i OLAŃCZUK-NEYMAN 2004 \\
\hline $\begin{array}{l}\text { Gronkowce he- } \\
\text { molizujace }\end{array}$ & $\begin{array}{l}\text { Agar Columbia } z \\
\text { krwia owcy }\end{array}$ & $10^{\circ} \mathrm{C}, 2-7 \mathrm{dni}$ & KOŁWZAN i współaut. $2012 a$ \\
\hline $\begin{array}{l}\text { Bakterie hemoli- } \\
\text { tyczne }\end{array}$ & $\begin{array}{l}\text { Agar bulionowy } z \\
\text { krwia }\end{array}$ & $37^{\circ} \mathrm{C}, 24 \mathrm{~h}$ & FILIPKOWSKA i współaut. 2000 \\
\hline Escherichia coli & Agar VRBL & $45^{\circ} \mathrm{C}$ & BRANDI i współaut. 2000 \\
\hline Escherichia coli & Agar Endo & $44^{\circ} \mathrm{C}, 48 \mathrm{~h}$ & HAAS i współaut. 2010 \\
\hline Escherichia coli & Agar Endo-LES & $37^{\circ} \mathrm{C}, 24 \mathrm{~h}$ & NOWOJEWSKI i MNISZEK 2006 \\
\hline $\begin{array}{l}\text { Escherichia coli, } \\
\text { bakterie grupy } \\
\text { coli }\end{array}$ & Agar m-FC & $\begin{array}{l}44-44,5^{\circ} \mathrm{C}, 24- \\
48 \mathrm{~h}\end{array}$ & $\begin{array}{l}\text { HEINONEN-TANSKI i współaut. 2009; VÍTĚZOVÁ i współaut. } \\
2012\end{array}$ \\
\hline $\begin{array}{l}\text { Bakterie grupy } \\
\text { coli i Enterobac- } \\
\text { teriaceae }\end{array}$ & Agar Endo & $37^{\circ} \mathrm{C}, 24-48 \mathrm{~h}$ & $\begin{array}{l}\text { BREZA-BORUTA 2016; BREZA-BORUTA i PALUSZAK 2007b; } \\
\text { GOFF i współaut. 1973; GOTKOWSKA-PŁACHTA i współaut. } \\
\text { 2008; HAAS i współaut. 2010; KOŁWZAN i współaut. } \\
\text { 2012b; KORZENIEWSKA i współaut. 2009; MICHAEKIEWICZ i } \\
\text { współaut. } 2011\end{array}$ \\
\hline $\begin{array}{l}\text { Bakterie grupy } \\
\text { coli }\end{array}$ & Agar VRBL & $37^{\circ} \mathrm{C}$ & BRANDI i współaut. 2000 \\
\hline $\begin{array}{l}\text { Bakterie grupy } \\
\text { coli }\end{array}$ & Agar CCA & $37^{\circ} \mathrm{C}, 24-48 \mathrm{~h}$ & KRUCZALAK i OLAŃCZUK-NEYMAN 2004 \\
\hline $\begin{array}{l}\text { Enterobacteria- } \\
\text { ceae }\end{array}$ & $\begin{array}{l}\text { Agar Mac Con- } \\
\text { key'a }\end{array}$ & $37^{\circ} \mathrm{C}, 24 \mathrm{~h}$ & $\begin{array}{l}\text { BUDZIŃSKA i współaut. 2011; GRISOLI i współaut. 2009; } \\
\text { SZYŁAK-SZYDŁOWSKI i współaut. } 2016\end{array}$ \\
\hline Enterococci & $\begin{array}{l}\text { Agar m-Entero- } \\
\text { coccus }\end{array}$ & $37^{\circ} \mathrm{C}$ & BRANDI i współaut. 2000 \\
\hline Enterococci & Agar KAA & $37^{\circ} \mathrm{C}, 24 \mathrm{~h}$ & BREZA-BORUTA i PALUSZAK 2007b \\
\hline $\begin{array}{l}\text { Enterococcus } \\
\text { faecalis }\end{array}$ & Slanetz-Bartley & $37^{\circ} \mathrm{C}, 48-72 \mathrm{~h}$ & $\begin{array}{l}\text { FRACCHIA i współaut. 2006; GOTKOWSKA-PŁACHTA i współ- } \\
\text { aut. 2008; KARRA i KATSIVELA 2007; KORZENIEWSKA i } \\
\text { współaut. } 2009\end{array}$ \\
\hline Clostridium sp. & Agar SPS & $37^{\circ} \mathrm{C}, 48 \mathrm{~h}$ & GRISOLI i współaut. 2009 \\
\hline Salmonella sp. & $\begin{array}{l}\text { Agar SS (Salmo- } \\
\text { nella - Shigella) }\end{array}$ & $37^{\circ} \mathrm{C}$ & BRANDI i współaut. 2000 \\
\hline Salmonella sp. & Agar BPL & $37^{\circ} \mathrm{C}, 24 \mathrm{~h}$ & BREZA-BORUTA i PALUSZAK 2007b \\
\hline Shigella sp. & Agar SS & $37^{\circ} \mathrm{C}$ & BRANDI i współaut. 2000 \\
\hline Aeromonas sp. & $\begin{array}{l}\text { m-Aeromonas } \\
\text { agar }\end{array}$ & $37^{\circ} \mathrm{C}$ & BRANDI i współaut. 2000 \\
\hline $\begin{array}{l}\text { Actinomycetes } \\
\text { (Actinobacteria) }\end{array}$ & Pochon & $\begin{array}{l}26-28^{\circ} \mathrm{C}, 3-14 \\
\text { dni }\end{array}$ & $\begin{array}{l}\text { BREZA-BORUTA 2016; BREZA-BORUTA i PALUSZAK 2007b; BU- } \\
\text { DZIŃSKA i współaut. 2011; FILIPKOWSKA i współaut. 2000; } \\
\text { GOTKOwSKA-PŁACHTA i współaut. 2013; GoTKOwSKA-PŁACHTA } \\
\text { i współaut. 2008; KOŁWZAN i współaut. 2012a; KOŁWZAN } \\
\text { i współaut. 2012b; KORZENIEWSKA i współaut. 2009; PA- } \\
\text { SMIONKA i współaut. } 2015\end{array}$ \\
\hline $\begin{array}{l}\text { Actinomycetes } \\
\text { (Actinobacteria) }\end{array}$ & $\begin{array}{l}\text { Syntetyczny agar } \\
\text { Gause'a }\end{array}$ & $28^{\circ} \mathrm{C}, 5 \mathrm{dni}$ & LI i współaut. 2013 \\
\hline $\begin{array}{l}\text { Actinomycetes } \\
\text { (Actinobacteria) }\end{array}$ & $\begin{array}{l}\text { Agar izolinowy } \\
\text { dla Actinomy- } \\
\text { cetes }\end{array}$ & $26^{\circ} \mathrm{C}, 7 \mathrm{dni}$ & VÎTĚZOVÁ i współaut. 2012 \\
\hline $\begin{array}{l}\text { Termofilne pro- } \\
\text { mieniowce }\end{array}$ & $\begin{array}{l}\text { Agar ze skrobia } \\
\text { kazeinowa }\end{array}$ & $\begin{array}{l}28^{\circ} \mathrm{C} \text { i } 48^{\circ} \mathrm{C} \\
5-10 \text { dni }\end{array}$ & FRACCHIA i współaut. 2006 \\
\hline
\end{tabular}


Tabela 2. Podłoża i warunki hodowli grzybów mikroskopowych stosowane w badaniach mikrobiologicznego zanieczyszczenia powietrza.

\begin{tabular}{|c|c|c|c|}
\hline Grzyby mikroskopowe & Podłoże & Warunki hodowli & Autor \\
\hline Grzyby & Sabouraud & $20-28^{\circ} \mathrm{C}, 1-7 \mathrm{dni}$ & $\begin{array}{l}\text { BRANDI i współaut. 2000; KRUCZALAK i OLAŃ- } \\
\text { CZUK-NEYMAN 2004; LI i współaut. 2013; MA- } \\
\text { EECKA-ADAMOWICZ i współaut. 2017; MICHAE- } \\
\text { KIEWICZ i współaut. 2018; NIAZI i współaut. } \\
2015\end{array}$ \\
\hline Grzyby & Sabouraud & $37^{\circ} \mathrm{C}, 24-48 \mathrm{~h}$ & AZEVEDO i współaut. 2014 \\
\hline Grzyby & $\begin{array}{l}\text { Agar brzeczkowy z kwasem } \\
\text { cytrynowym }\end{array}$ & $26^{\circ} \mathrm{C}, 72 \mathrm{~h}$ & BREZA-BORUTA i PALUSZAK 2007b \\
\hline Grzyby & Agar RBC & $26-30^{\circ} \mathrm{C}, 3-7 \mathrm{dni}$ & $\begin{array}{l}\text { BUDZIŃSKA i współaut. 2011; GUO i współ- } \\
\text { aut. 2014; KoRZENIEWSKA i współaut. } 2009\end{array}$ \\
\hline Grzyby & Malt Extract Agar & $25-30^{\circ} \mathrm{C}, 3-5 \mathrm{dni}$ & $\begin{array}{l}\text { CYPROWSKI i współaut. 2008; KARRA i KAT- } \\
\text { SIVELA 2007; KRISTANTO i ROSANA 2017; LI i } \\
\text { współaut. } 2016\end{array}$ \\
\hline Grzyby & Agar $z$ brzeczka & $25^{\circ} \mathrm{C}, 3-7 \mathrm{dni}$ & $\begin{array}{l}\text { BREZA-BORUTA 2016; CYPROWSKI i współaut. } \\
2008\end{array}$ \\
\hline Grzyby & Agar Czapka & $\begin{array}{lrr}25^{\circ} \mathrm{C} ; & 5^{\circ} \mathrm{C} & \text { lub } \\
37^{\circ} \mathrm{C} ; 7 & \mathrm{dni} & \\
\end{array}$ & $\begin{array}{l}\text { CYPROWSKI i współaut. 2008; GOTKOWSKA- } \\
\text {-PŁACHTA i współaut. } 2013\end{array}$ \\
\hline Grzyby & Agar Czapek-Doxa & $25-26^{\circ} \mathrm{C}, 2-7 \mathrm{dni}$ & $\begin{array}{l}\text { KOEWZAN i współaut. 2012b; MICHAEKIEWICZ } \\
\text { i współaut. 2011; VÍTĚZOVÁ i współaut. } 2012\end{array}$ \\
\hline Grzyby & Waksman & $26^{\circ} \mathrm{C}, 7 \mathrm{dni}$ & $\begin{array}{l}\text { KOŁWZAN i współaut. 2012b; MICHAŁKIEWICZ i } \\
\text { współaut. } 2011\end{array}$ \\
\hline Grzyby & $\begin{array}{l}\text { Agar PDA (ziemniaczano- } \\
\text {-dekstrozowy) }\end{array}$ & $25^{\circ} \mathrm{C}, 4 \mathrm{dni}$ & BREZA-BORUTA 2016 \\
\hline Termotolerancyjne grzyby & Agar DG-18 & $37^{\circ} \mathrm{C}, 7 \mathrm{dni}$ & BAUER i współaut. 2002 \\
\hline Grzyby drożdżopodobne & Sabouraud $z$ TTC & $26^{\circ} \mathrm{C}, 3-5 \mathrm{dni}$ & KOEWZAN i współaut. 2012a \\
\hline Grzyby pleśniowe & $\begin{array}{l}\text { Sabouraud } z \text { chloramfeni- } \\
\text { kolem }\end{array}$ & $26^{\circ} \mathrm{C}, 3-5 \mathrm{dni}$ & KOEWZAN i współaut. 2012a \\
\hline Drożdże i pleśnie & Sabouraud & $30^{\circ} \mathrm{C}, 5 \mathrm{dni}$ & FILIPKOWSKA i współaut. 2000 \\
\hline Mezofilne pleśnie & $\begin{array}{l}\text { Agar DG-18 z chloramfeni- } \\
\text { kolem }\end{array}$ & $25^{\circ} \mathrm{C}, 5-7 \mathrm{dni}$ & $\begin{array}{l}\text { BAUER i współaut. 2002; TEIXEIRA i współ- } \\
\text { aut. } 2013\end{array}$ \\
\hline
\end{tabular}

MAS-100 i kaskadowy impaktor Andersena. Decydujaca rolę w badaniach bioaerozoli odgrywa zarówno dokładna znajomość pobranego powietrza, jak i możliwość porównywania wyników badań przy stosowaniu urzadzeń o podobnej średnicy głowic przepuszczających powietrze na standardowe płytki Petriego o średnicy $90 \mathrm{~mm} z$ gotowymi pożywkami, a także zbliżone wartości średnicy odcięcia $\left(\mathrm{d}_{50}\right)$.

W cytowanych powyżej pracach, omawiajacych sposób poboru powietrza do badań mikrobiologicznych na terenach oczyszczalni ścieków, autorzy zwracaja uwage na liczebność wykrytych mikroorganizmów na różnych etapach oczyszczania ścieków, a także ich zróżnicowanie i negatywne oddziaływanie na pracowników i mieszkańców okolicznych terenów. Często zdiagnozowane drobnoustroje zaliczane sa do chorobotwórczych lub potencjalnie patogennych mikroorganizmów.

\section{PODŁOŻA HODOWLANE}

W pobranych próbkach powietrza do badań mikrobiologicznych należy oznaczyć liczebność i skład drobnoustrojów. Niezależnie od metody poboru próbek bioaerozoli oraz warunków ich hodowli i identyfikacji, obliczenia liczebności msikroorganizmów zawartych w powietrzu zwykle przeliczane sa na wspólna jednostke $1 \mathrm{~m}^{3}$ powietrza. Do hodowli drobnoustrojów wykorzystuje się pożywki (podłoża) oraz stosuje się różne warunki ich inkubacji (czas i temperatura). Zwykle w badaniach mikrobiologicznego zanieczyszczenia powietrza hodowane sa grupy bakterii oraz grzyby mikroskopowe, które rosna na różnych pożywkach. Ponadto stosowanie sa różne podłoża do hodowli tych samych drobnoustrojów. W Tabelach 1-2 zestawiono badane grupy mikroorganizmów, wykorzystywane pożywki, temperaturę i czas 
hodowli oraz autorów prac, którzy omawiaja te metody hodowlane.

Analizując rodzaj stosowanych pożywek do badań mikrobiologicznych można zauważyć, że dla oceny ogólnej liczebności bakterii najczęściej wykorzystuje się agar odżywczy lub wzbogacony, dla bakterii Pseudomonas fluorescens podłoże King B, dla gronkowców agar $z$ mannitolem, dla bakterii grupy coli podłoże Endo, dla promieniowców (Actinobacteria) pożywkę Pochona, natomiast dla grzybów mikroskopowych podłoże Sabouraud. W przypadku innych drobnoustrojów pożywki są dość zróżnicowane. Jednak porównujacc warunki hodowli (temperatura, czas) można stwierdzić, że występuja tu niekiedy znaczne różnice. Najczęściej w hodowli bakterii zwiazanych $z$ człowiekiem stosuje się temperaturę $37^{\circ} \mathrm{C}$, dla bakterii psychrofilnych żyjących w środowisku zewnętrznym 20 do $22^{\circ} \mathrm{C}$, natomiast dla grzybów $25^{\circ} \mathrm{C}$. Taka sytuacja powoduje, że końcowa ocena stopnia mikrobiologicznego zanieczyszczenia powietrza przy stosowaniu różnych metod poboru bioaerozoli, różnych pożywek i warunków inkubacji, nie zawsze jest porównywalna. Przyczyna tego jest najczęściej brak znormalizowanych przepisów (wytycznych, norm, dyrektyw, itp.) obowiazujacych w poszczególnych państwach, we wszystkich krajach lub np. na terenie Unii Europejskiej, czy w państwach Ameryki Północnej i Południowej, według których można jednakowo ocenić stopień mikrobiologicznego zanieczyszczenia powietrza.

\section{PODSUMOWANIE}

Obiekty komunalne, w tym oczyszczalnie ścieków są antropogennym źródłem emisji bioaerozoli. W licznych publikacjach omawiajacych mikrobiologiczne zanieczyszczenie powietrza na terenach oczyszczalni ścieków przedstawiane sa różne metody poboru próbek powietrza do badań. Ze względu na wymagana dokładność pomiarów, obecnie najczęściej stosuje się metody wolumetryczne, które gwarantuja dokładne określenie objętości badanego powietrza.

W metodach hodowlanych do zidentyfikowania i obliczenia składników bioaerozoli wykorzystuje się różne podłoża (pożywki). Warunki inkubacji (czas i temperatura) sa bardzo zróżnicowane, mimo że dotycza hodowli tych samych bakterii i grzybów mikroskopowych.

Ze względu na zróżnicowanie metod poboru powietrza i warunków hodowli drobnoustrojów, bardzo trudno jest niekiedy porównać wyniki badań uzyskane przez różnych autorów.
Brakuje ujednoliconych przepisów dotyczacych badania bioaerozoli, które obowiązywałyby np. w UE lub na całym świecie.

$$
\text { Streszczenie }
$$

W artykule przedstawiono podstawowe metody poboru i badań bioaerozolu emitowanego do atmosfery w otoczeniu oczyszczalni ścieków. Dokonano przeglądu literatury (ponad 100 pozycji), w której cytowane sa liczne prace dotyczace mikrobiologicznego zanieczyszczenia powietrza na terenie i w sąsiedztwie oczyszczalni ścieków. $Z$ tego względu, że każda $z$ metod poboru próbek powietrza jest inna, bardzo trudno jest niekiedy porównać wyniki badań prowadzonych przez różnych autorów, badających powietrze różnymi metodami. Obecnie najbardziej powszechne sa wolumetryczne sposoby poboru powietrza. W tym celu wykorzystuje się liczne urządzenia o różnych zasadach działania. W dostępnej literaturze stwierdza się także stosowanie bardzo różnych podłoży do hodowli tych samych dOrobnoustrojów. W załączonych tabelach zestawiono najczęściej badane grupy mikroorganizmów, wykorzystywane pożywki, temperaturę i czas hodowli oraz autorów prac, którzy omawiają te metody hodowlane. Przyczyna takiej sytuacji jest najczęściej brak znormalizowanych przepisów obowiazujacych w poszczególnych państwach, we wszystkich krajach lub np. na terenie Unii Europejskiej, według których można jednakowo ocenić stopień mikrobiologicznego zanieczyszczenia powietrza.

\section{LITERATURA}

AdAmus-BialeK W., WaWszczaK M., ŚwiercZ A., 2015. Impact of sewage treatment plant on local environment. Proc. ECOpole 9, 397-404.

Ahmed M., Schulz J., HARTUNG J., 2013. Air samplings in a Campylobacter jejuni positive laying hen flock. Ann. Agr. Env. Med. 20, 1620.

AiZENBERG V., REPONEN Y., GRINSHPUN S. A., WilleKe K., 2000. Performance of Air-O-Cell, Burkard, and Button samplers for total enumeration of airborne spores. Am. Ind. Hyg. Assoc. J. 61, 855-864.

Alvarez A. J., ButTner M. P., STETZENBACH L. D., 1995. PCR for bioaerosol monitoring: sensitivity and environmental interference. Appl. Environ. Microb. 61, 3639-3644.

ANDERSEN A. A., 1958. New sampler for the collection, sizing and enumeration of viable airborne particles. J. Bacteriol. 76, 357-375.

Azevedo M. L. R. S., Couto M. A. P. G., Leite S. G. F., Azevedo B. R. S., Almeida P. A., PROCóPIO A. S., Silva S. A., 2014. Evaluation of air samplers systems in the monitoring of bioaerosols at wastewater treatment plants. IJET-IJENS, 14, 3, 48-55.

Bartlett K. H., LEe K. S., Stephens G., Black W., BRAUER M., COPES R., 2002. Evaluating Indoor Air Quality: Test Standards for Bioaerosols, School of Occupational and Environmental Hygiene. University of British Columbia, Vancouver, Canada.

BAUER H., FUERHACKER M., ZiBUSCHKA F., SCHMID H., Puxbaum H., 2002. Bacteria and fungi in aerosols generated by two different types of wastewater treatment plants. Water Res. 36, 3965-3970.

Bellin P., SCHILlinger J., 2001. Comparison of field performances of the Andersen N6 Single Stage and the SAS sampler for airborne fungal propagules. Indoor Air 11, 65-68. 
BRANDi G., Sisti M., Amagliani G., 2000. Evaluation oft he environmental impact of microbial aerosols generated by wastewater treatment plants utilizing different aeration systems. J. Appl. Microbiol. 88, 845-852.

BRANDL H., BACHOFEN R., BISCHOFF M., 2005. Generation of bioaerosols during manual mail unpacking and sorting. J. Appl. Microbiol. 99, 1099-1107.

BRAGOSZEWSKA E., KowAL A., PASTUSZKA J. S., 2013. Bacterial aerosol occurring in atmospheric air in Gliwice, Upper Silesia, Poland. ACEE 4, 61-66.

BREZA-BORUTA B., 2016. The assessment of airborne bacterial and fungal contamination emitted by a municipal landfill site in Northern Poland. Atmos. Pollut. Res. 7, 1043-1052.

BREZA-BORUTA B., PALUSZAK Z., 2007a. Wystepowanie gronkowców antybiotykoopornych $w$ powietrzu atmosferycznym na terenie oczyszczalni ścieków. Med. Weter. 63, 717-720.

BREZA-BORUTA B., PALUSZAK Z., 2007b. Influence of water treatment plant on microbiological composition of air bioaerosol. Pol. J. Environ. Stud. 16, 663-670.

BUDZIŃSKA K., JUREK A., SZEJNIUK B., MichALSKA M., WROŃSKI G., 2011. Mikrobiologiczne zanieczyszczenie powietrza na terenie oczyszczalni ścieków komunalnych. Rocz. Ochr. Sr. 13, 1543-1558.

CYPROWSKI M., BUCZYŃSKA A., SZADKOWSKA-STAŃCZYK I., 2006. Ocena narażenia na bioaerozole pracowników kanalizacji. Med. Pracy 57, 525530.

CYPROWSKI M., SOWIAK M., SOROKA P. M., BUCZYŃSKA A., KOZAJDA A., SZADKOWSKA-STAŃCZYK I., 2008. Ocena zawodowej ekspozycji na aerozole grzybowe $w$ oczyszczalniach ścieków. Med. Pracy 59, 365-371.

CYPROWSKI M., STOBNICKA-KUPIEC A., ŁAWNICZEK-WAECZYK A., BAKAL-KIJEK A., GOŁOFIT-SZYMCZAK M., GÓRNY R. L., 2018. Anaerobic bacteria in wastewater treatment plant. Int. Arch. Occup. Environ. Health 91, 571579.

DinG P. H., WANG C. S., 2001. Effect of sampling time on the total recovery of AGI-30 impingers for E. coli aerosols. Aerosol Air Qual. Res. 1, 31-36.

DiNG W., LI L., HAN Y., LIU J., 2015. Site-related and seasonal variation of bioaerosol emission in an indoor wastewater treatment station: level, characteristics of particle size, and microbial structure. Aerobiologia 32, 211-224.

DUTKIEWICZ J., GÓRNY R. L., 2002. Biologiczne czynniki szkodliwe dla zdrowia - klasyfikacja $i$ kryteria oceny narażenia. Med. Pracy 53, 29-39.

EN 50082-1, 1997. Electromagnetic compatibility generic immunity standard - residential, commercial and light industry.

Fathi S., HaJizadeH Y., NiKaEen M., GoRbani M., 2017. Assessment of microbial aerosol emissions in an urban wastewater treatment plant operated with activated sludge process. Aerobiologia 33, 507-515.

FANNin K. F., VANA S. C., JaKuBOWsKi W., 1985. Effect of an activated sludge wastewater treatment plant on ambient air densities of aerosols containing bacteria and viruses. Appl. Environ. Microb. 49, 1191-1196.

FILIPKOWSKA Z., JANCZUKOWICZ W., KRZEMIENIEWSKI M., PESTA J., 2000. Microbiological air pollution of the surrounding of Waste Water Treatment Plant with activated-sludge aerated by horizontal rotors. Pol. J. Environ. Stud. 9, 273-280.

FilipkOWSKA Z., GotKowska-PŁACHTA A., KorZENIEWSKA E., 2008. Grzyby pleśniowe oraz drożdże $i$ grzyby drożdżoidalne $w$ powietrzu atmosferycznym na terenie $i w$ otoczeniu oczyszczalni ścieków z systemem stawów napowietrzanych $i$ stabilizacyjnych. Woda Środowisko-Obszary Wiejskie 8, 69-82.

Fracchia L., PIETRONAVE S., Rinaldi M., MARTINOTTI M. G., 2006. Site-related airborne biological hazard and seasonal variations in two wastewater treatment plants. Water Res. 40, 1985-1994.

Gangamma S., Patil R. S., MukherJi S., 2011. Characterization and proinflammatory response of airborne biological particles from wastewater treatment plants. Environ. Sci. Technol. 45, 3282-3287.

Goff G. D, Spendlove J. C. AdAms A. P., NichOLES P. S., 1973. Emission of microbial aerosols from sewage treatment plants that use trickling filters. Effects of environmental conditions. Health Serv. Rep. 88, 640-652.

GotKOWSKA-PŁACHTA A., FILIPKOWSKA Z., KORZENIEWSKA E., JANCZUKOWICZ W., 2008. Zanieczyszczenia mikrobiologiczne powietrza atmosferycznego na terenie $i w$ otoczeniu oczyszczalni ścieków systemem stawów napowietrzanych $i$ stabilizacyjnych. Woda Środowisko-Obszary Wiejskie 8, 83-98.

GotKOWSKA-PŁACHTA A., FILIPKOWSKA Z., KORZENIEWSKA E., JANCZUKOWICZ W., DiXON B., Go¿AŚ I., SZWALGIN D., 2013. Airborne Microorganisms Emitted from Wastewater Treatment Plant Treating Domestic Wastewater and Meat Processing Industry Wastes. Clean-Soil Air Water 41, 5, 429-436.

GregOVÁ G., VENGLOVSKÝ J., VARGOVÁ M., ONDRAŠOVIČOVÁ O., ONDRAŠOVIČ M., SASÁKOVÁ N., KudRIKOVÁ D., LAKTIČOVÁ K., 2008. Bioaerosols produced by wastewater treatment plant. Folia Veterinaria 52, 59-61.

Grisoli P., Rodolfi M., VIllani S., Grignani E., COTTICA D., BerRi A., PICCO A. M., DACARRO C., 2009. Assessment of airborne microorganism contamination in an industrial area cha racterized by an open composting facility and a wastewater treatment plant. Environ. Res. 109, 135-142.

Guo X.', Wu P., Ding W., Zhang W., Li L., 2014. Reduction and characterization of bioaerosols in a wastewater treatment station via ventilation. J. Environ. Sci. 26, 1575-1583.

HAAS D., UNTEREgGer M., HABIB J., GALler H., MARTH E., REINTHALER F. F., 2010. Exposure to Bioaerosol from Sewage Systems. Water Air Soil Pollut. 207, 49-56.

Han Y., Wang Y., Li L., XU G., LiU J., Yang K., 2018. Bacterial population and chemicals in bioaerosols from indor environment: Sludge dewatering houses in nine municipal wastewater treatment plants. Sci. Total Environ. 618, 469-478.

Heinonen-TANski H., Reponen T., KoIvunen J., 2009. Airborne enteric coliphages and bacteria in sewage treatment plants. Water Res. 43, 2558-2566.

Hung H. F., Kuo Y. M., ChIEN C. C., Chen C. C., 2010. Use of floating balls for reducing bacterial aerosol emissions from aeration in wastewater treatment processes. J. Hazard. Mater. 175, 866-871.

Iso 14698-1/2, 2003. Cleanrooms and associated controlled environments - Biocontamination control - Part 1: General principles and meth- 
ods. Part 2: Evaluation and interpretation of biocontamination data.

KARL D. M., 1980. Cellular nucleotide measurements and applications in microbial ecology. Microbiol. Rev. 44, 739-796.

KARRA S., KATSIVELA E., 2007. Microorganisms in bioaerosol emissions from wastewater treatment plants during summer at a Mediterranean site. Water Res. 41, 1355-1365.

KIM S. Y., KIM Z. Y., LEE S., Ko G. P., 2011. Comparison of molecular and total ATP-based analytical methods with culture for the analysis of bioaerosols. Sci. Total Environ. 409, 1732-1737.

KO€WZAN B., JADCZYK P., PASTERNAK G., PAWLIK M., KRAWCZYŃSKA M. K., MOLSKA J., KLEIN J., 2012a. Ocena zasiegu oddziaływania oczyszczalni ścieków komunalnych na stan sanitarny powietrza. [W:] Ochrona powietrza atmosferycznego: wybrane zagadnienia. MUSIALIK-PIOTROWSKA A., RUTKOWSKI J. D. (red.). PZITS, Wrocław, 141-149.

KolWZAN B., JADCZYK P., PASTERnAK G., GŁUsZCZAK J., PAWLIK M., KRAWCZYŃSKA M., KLEIN J., RYBAK J., 2012b. Ocena stanu sanitarnego powietrza $w$ otoczeniu wybranej oczyszczalni ścieków. Ochr. Sr. 34, 9-14.

KORZENIEWSKA E., 2011. Emission of bacteria and fungi in the air from wastewater treatment plants - a review. Front. Biosci. (Schol Ed.) 1, 393-407.

KORZENIEWSKA E., FILIPKOWSKA Z., GOTKOWSKA-PŁACHTA A., 2007. Miejska oczyszczalnia ścieków z komorami osadu czynnego, napowietrzanymi aeratorami typu Celpox jako emitor bakterii $z$ rodziny Enterobacteriaceae do powietrza. Ochr. Środ. Zasob. Natur. 32, 184189.

KORZENIEWSKA E., FILIPKOWSKA Z., GOTKOWSKA-PŁACHTA A, JANCZUKOWICZ W., 2008. Bakteriologiczne zanieczyszczenie powietrza na terenie $i w$ otoczeniu oczyszczalni ścieków $z$ systemem filtrów gruntowo-roślinnych. Woda Środowisko-Obszary Wiejskie 8, 161-173.

KORZENIEWSKA E., FILIPKOWSKA Z., GOTKOWSKA-PŁAchTA A., JANCZUKOWICZ W., DiXONC B., CZUŁOWSKA M., 2009. Determination of emit ted airborne microorganisms from a BIO-PAK wastewater treatment plant. Water Res. 43, 2841-2851.

Kowalski M., Wolany J., Pastuszka J. S., PŁAZa G., WlazŁo A., Ulfig K., Malina A., 2017. Characteristics of airborne bacteria and fungi in some Polish wastewater treatment plants. Int. J. Environ. Sci. Te. 14, 2181-2192.

Kristanto G. A., Rosana F. N., 2017. Analysis of Microbial Air Quality in the Surrounding Hospital's Wastewater Treatment Plants in Jakarta, Indonesia. MATEC Web of Conferences, 138, $1-8$.

KROGUlSKI A., 2006. Metody oznaczania ogólnej liczby bakterii $w$ powietrzu atmosferycznym $i$ wewnatrz pomieszczen. Rocz. Panstw. Zakl. Hig. $57,1,1-7$.

KRUCZALAK K., OlańCZUK-NEYMAN K., 2004. Microorganisms in the air over wastewater treat ment plants. Pol. J. Environ. Stud. 13, 537542.

KRZYSZTOFIK B., 1992. Mikrobiologia powietrza. Wydawnictwo Politechniki Warszawskiej.

Li J., Zhou L., Zhang X., Xu C., DONG L., YaO M., 2016. Bioaerosol emissions and detection of airborne antibiotic resistance genes from a wastewater treatment plant. Atmos. Environ. $124,404-412$
LI Y., ZHANG H., QIU X., ZHANG Y., WANG H., 2013. Dispersion and risk assessment of bacterial aerosols emitted from rotating-brush aerator during summer in a wastewater treatment plant of Xi'an, China. Aerosol Air Qual. Res. 13, 1807-1814.

LIN W. -H., Li C. -S., 1999. Evaluation of impingement and filtration methods for yeast bioaerosol sampling. Aerosol Sci. Tech. 30, 119-126.

M`eheust D., GangneuX J. P., Cann P. L., 2013. Comparative Evaluation of Three Impactor Samplers for Measuring Airborne Bacteria and Fungi Concentrations. J. Occup. Environ. Hyg. $10,455-459$.

MaCNEIL L., KaURI T., ROBERTSON W., 1995. Molecular techniques and their potential application in monitoring the microbiological quality of indoor air. Can. J. Microbiol. 41, 657-665.

MALAKOOTIAN M., RADHAKRISHNA N., MAZANDARANY M. P., Hossaini H., 2013. Bacterial-aerosol emission from wastewater treatment plant. Desalin. Water Treat. 51, 4478-4488.

MAŁECKA-ADAMOWICZ M., DONDERSKI W., DOKŁADNA W., 2011. Microflora of air in the sewage treatment plant of Kapuściska in Bydgoszcz. Pol. J. Environ. Stud. 20, 1235-1242.

MAŁECKA-ADAMOWICZ M., KUBERA Ł., DONDERSKI W., KOLET K., 2016. Microbial air contamination on the premises of the sewage treatment plant in Bydgoszcz (Poland) and antibiotic resistance of Staphylococcus spp. Arch. Environ. Prot. 43, 58-65.

MaRchand G., Lavoie J., LazURe L., 1995. Bioaerosols in a Municipal Solid Waste Recycling and Composting Plant. Air Waste Management Assoc. 45, 778-781.

MARTINEZ K. F., RAO C. Y., BuRTON N. C., 2004. Exposure assessment and analysis for biological agents. Grana 43, 193-204.

MAY K. R., HARPER J., 1957. The efficiency of various liquid impinger samplers in bacterial aerosols. Brit. J. Industr. Medi. 14, 287-297.

MiCHAŁKIEWICZ M., 2006. Mikroorganizmy wystepujace $w$ wodzie. Wodociagi Kanalizacja 7/8, 26-28.

MichalKIEWICZ M., PRUSS A., DYMACZEWSKI Z., JEŻ-WALKOWIAK J., KWAŚNA S., 2011. Microbiological air monitoring around municipal wastewater treatment plants. Pol. J. Environ. Stud. 20, 1243-1250.

MichaEKIEWICZ M., KRUSZELNICKA I., WidOMSKA M., 2018. The variability of the concentration of bioaerosols above the chambers of biological wastewater treatment. Ecol. Chem. Eng. S. $25,267-278$.

Mrowiec B., SuschKa J., 1995. Wpływ procesów oczyszczania ścieków na przenoszenie zanieczyszczeń do atmosfery. Gaz Woda Technika Sanitarna 3, 92-95.

NEVAlAinen A., PASTUSZKA J., LIEBHABER F., WilLEKE K., 1992. Performance of bioaerosol samplers: collection characteristics and sampler design consideration. Atmos. Environ. 26A, 531-540.

Niazi S., Hassanvand M. S., Mahvi A. H., NabizaDEH R., ALIMOHAMMADI M., NABAVI S., FARIDI S., Dehghani A., Hoseini M., MoRadi-Joo M., MOKAMEL A., KASHANI H., YARALI N., YUNESIAN M., 2015. Assessment of bioaerosol contamination (bacteria and fungi) in the largest urban wastewater treatment plant in the Middle East. Environ. Sci. Pollut. Res. 22, 1601416021.

NowOJEWSKi A., MNiszeK W., 2006. Analiza narażenia zawodowego pracowników na szkodli- 
we czynniki biologiczne $w$ typowej miejskiej oczyszczalni ścieków. ZN WSZOP 1, 7-34.

ORSINI M., LAURENTI P., BONINTI F., ARZANI D., LANNI A., ROMANO-SPICA V., 2002. A molecular typing approach for evaluating bioaerosol exposure in wastewater treatment plant workers. Water Res. 36, 1375-1378.

ÖZDEMIR M., GÜNDEM N. S., BAYSAL B., 2010. Investigation of bacterial counts in air at intensive care units and operating rooms. Anatol. J. Clin. Investig. 4, 1-4.

Pascual L., Pérez-LuZ S., YÁÑez M. A., SANTAMARIA A., Gibert K., SAlgot M., APRAIZ D., CATALÁN V., 2003. Bioaerosol emission from wastewater treatment plants. Aerobiologia 19, 3-4, 261-270.

PASTUSZKa J. S., IWASIEWICZ P., BRAgoszewska E. 2013. Preliminary testing of a new bioaerosols sampler developed for the measurements of low and medium concentration levels of airborne bacteria and fungi. Environ. Prot. Eng. 39, 129-138.

PAŚMIONKA I., GALUS-BARChan A., OleKSIEWICZ B. 2015. Mikrobiologiczne zanieczyszczenie powietrza atmosferycznego na terenie Grupowej Oczyszczalni Scieków w Chrzanowie. Polish J. Agronomy 20, 3-8.

PATENTALAKIS N., PANTIDOU A., KALOGERAKIS N. 2008. Determination of Enterobacteria in Air and Wastewater Samples from a Wastewater Treatment Plant by Epi-Fluorescence Microscopy. Water Air Soil Pollut. Focus 8, 107-115.

PN -89/Z-04008/08, 1989. Ochrona czystości powietrza. Pobieranie próbek. Pobieranie próbek powietrza atmosferycznego (imisja) do badań mikrobiologicznych metoda aspiracyjna $i$ sedymentacyjna.

PN -89/Z-04111/01, 1989. Ochrona czystości powietrza. Badania mikrobiologiczne. Postanowienia ogólne i zakres normy.

PN -89/Z-04111/02, 1989. Ochrona czystości powietrza. Badania mikrobiologiczne. Oznaczanie liczby bakterii $w$ powietrzu atmosferycznym (imisja) przy pobieraniu próbek metoda aspiracyjna $i$ sedymentacyjna.

PN -89/Z-04111/03, 1989. Ochrona czystości powietrza. Badania mikrobiologiczne. Oznaczanie liczby grzybów mikroskopowych $w$ powietrzu atmosferycznym (imisja) przy pobieraniu próbek metoda aspiracyjna $i$ sedymentacyjna.

RANAlli G., PRINCIPI P., SORLINI C., 2000. Bacterial aerosol emission from wastewater treatment plants: Culture methods and bio-molecular tools. Aerobiologia 16, 39-46.

SAwYer B., ElENBOGEN G., RaO K. C., O’Brien P., ZENZ D. R., LUE-HING C., 1993. Bacterial aerosol emission rates from municipal wastewater aeration tanks. Appl. Environ. Microb. 59, 3183-3186.

Schafer M. P., MARTinez K. F., Mathews E. S., 2003. Rapid detection and determination of the aerodynamic size range of airborne mycobacteria associated with whirlpools. Appl. Occup. Environ. Hyg. 18, 41-50.

SEETHA N., BHARGAVA R., GURJAR B. R., 2013. Gaseous and bioaerosol emissions from municipal wastewater treatment plants. J. Environ. Sci. Eng. 55, 517-536.

SHRAVANTHI M. C., KUMAR N. R., REDdy T. B., 2016. A study on isolation and identification of airborne bacteria at three different sewage treatment plant locations in Visakhapatnam City, A.p. IJSR 5, 75-77.
STEWART I. W., LEAVER G., FUTTER S. J., 1997. The enumeration of aerosolized Saccharomyces cerevisiae using bioluminescent assay of total adenylates. J. Aerosol Sci. 28, 511-523.

SZYŁAK-SZYDŁOWSKI M., KULIG A., MIAŚKIEWICZ-PESKA E., 2016. Seasonal changes in the concentrations of airborne bacteria emitted from a large wastewater treatment plant. Int. Biodeter. Biodegr. 115, 11-16.

Teixeira J. V., Miranda S., Monteiro R. A. R., LOPES F. V. S., MADUREIRA J., Silva G. V., Pestana N., Pinto E., Vilar V. J. P., BoavenTURA R. A. R., 2013. Assessment of indoor airborne contamination in a wastewater treatment plant. Environ. Monit. Assess. 185, 5972.

THORN J., BEIJER L., JONSSON T., RYLANDER R., 2002. Measurement strategies for the determination of airborne bacterial endotoxin in sewage treatment plants. Ann. Occup. Hyg. 46, 549-554.

ThORNE P. S., KieKhaEFER M. S., WhitTen P., DOMHAM K. J., 1992. Comparison of Bioaerosol Sampling Methods in Barns Housing Swine. Appl. Environ. Microb. 58, 2543-2551.

TOMASI C., LUPI A., 2017. Primary and secondary sources of atmospheric aerosol. [W:] Atmospheric aerosols: Life cycles and effects an air quality and climate. TOMASI C., FUZZI S., KoKHANOVSKY A. (red.). Wiley-VCH Verlag $\mathrm{GmbH} \& \mathrm{Co}$. KGaA, 1-86.

UhrbRAND K., Schultz A. C., KoIVISTO A. J., NiElsen U., MADSEN A. M., 2017. Assessment of airborne bacteria and noroviruses in air emission from a new highly-advanced hospital wastewater treatment plant. Water Res. 112, 110-119.

VANTARAKIS A., PAPARRODOPOULOS S., KOKKINOS P., VANTARAKIS G., FRAGOU K., DETORAKIS I., 2016. Impact on the quality of life when living close to a municipal wastewater treatment plant. J. Environ. Public Health, ID 8467023.

Vítězová M., Vítěz T., MLEJNKOVÁ H., LOŠÁK T., 2012. Microbial contamination of the air at the wastewater treatment plant. Acta Univ. Agric. Silvic. Mendelianae Brun. 60, 233-239.

WANG Y., LI L., HAN Y., LIU J., YANG K., 2018. Intestinal bacteria in bioaerosols and factors affecting their survival in two oxidation ditch process municipal wastewater treatment plants located in different regions. Ecotox. Environ. Safe. 154, 162-170.

Williams R. H., WARD E., MCCARTNEY H. A. 2001. Methods for integrated air sampling and DNA analysis for detection of airborne fungal spores. Appl. Environ. Microb. 67, 24532459.

WLAZEO A., PASTUSZKA J. S., ŁUDZEŃ-IZBiŃSKA B., 2002. Ocena narażenia na aerozol bakteryjny pracowników niedużej oczyszczalni ścieków. Med. Pracy 53, 109-114.

YAO M., MAINEliS G., 2006. Investigation of CutOff Sizes and Collection Efficiencies of Portable Microbial Samplers. Aerosol Sci. Technol. 40, 595-606.

ZENG Q. Y., WESTERMARK S. O., RASMUSON-LESTANDER A., WANG X. R., 2004. Detection and quantification of Wallemia sebi in aerosols by realtime $P C R$, conventional $P C R$, and cultivation. Appl. Environ. Microb. 70, 7295-7302. 
KOSMOS Vol. 68, 3, 475-487, 2019

\author{
Michat MichaŁKIEWICZ
}

Poznan University of Technology, Institute of Environmental Engineering, 4 Berdychowo Str., 61-138 Poznań, E-mail: Michal.Michalkiewicz@put.poznan.pl

METHODS FOR EVALUATION OF MICROBIOLOGICAL CONTAMINATION OF AIR - A LITERATURE REVIEW

\title{
Summary
}

This study presents the fundamental methods used for sampling and study of bioaerosols emitted to the atmosphere near wastewater treatment plants. Particular attention was paid to the literature reviews, which cite numerous reports regarding microbiological contamination of air on the area of wastewater treatment plants and in their vicinity. Due to the fact that each method of air sampling is different, it is challenging to compare the results obtained by different authors who study air using different methods. Currently, the most common are volumetric methods of air sampling. In the available literature there are reports on the use of various media for the cultivation of the same microorganisms. In the attached tables lists the studied groups of microorganisms, the used media, temperature and time of cultivation as well as the authors of reports, which discuss these cultivation methods. The reason for such situation is usually associated with the lack of standardized regulations applicable in specific countries, in all countries or e.g. within the European Union, which would allow for an equal evaluation of microbial air contamination.

Key words: air sampling, bioaerosol studies, bioaerosols, medium, wastewater treatment plants 